\title{
Strategi Penginjilan Terhadap Penjangkauan Suku Melayu Riau Di Daik Lingga-Kepulauan Riau
}

\author{
Selvyen Sophia, ${ }^{1}$ Fanolo Telaumbanua ${ }^{2}$, Septerianus Waruwu ${ }^{3}$ \\ Prodi Teologi, STT Real Batam \\ Prodi Teologi, STT Real Batam \\ Prodi Teologi, STT Real Batam \\ selvinchute99@gmail.com
}

\begin{abstract}
The Malay tribe has existed in the archipelago with a long period. But the impact of evangelism compared to other tribes is not seen. There are inhibiting factors of evangelism in this area so that no significant impact will be seen on the gospel. So that this tribe does not reject the Gospel that is conveyed, it takes a strategy in evangelism.In connection with that, in writing this thesis, the researcher formulated the problem as follows: First, what is the state of the Malay civilized society in Daik-Lingga? Second, what is the gospel preaching strategy that can be done to reach out to the Malays in Daik-Lingga? Researchers approached this tribe by using qualitative research ethnographic methods in the Malay tribe in Daik-Lingga to obtain data on the roots that inhibit the preaching of the gospel in the Malay tribe in Daik Lingga and effective gospel preaching strategies that can be used in outreaching this tribe. From the data collected, the researchers found that Malay tribes in Daik-Lingga did not accept the Gospel due to environmental factors, the majority of Muslims who did not want a new cultural establishment in their area and lay Christians who had not been taught about Malay tribal outreach.
\end{abstract}

Keywords: Gospel, Strategy, Outreach, Malay, Daik- Lingga

\begin{abstract}
Abstrak
Suku Melayu telah ada di nusantara dengan suatu periode yang sudah lama. Tetapi dampak dari penginjilan dibandingkan dengan suku lain tidaklah terlihat. Ada faktor penghambat dari penginjilan dalam daerah ini sehingga tidak terlihat dampak yang signifikan akan Injil . Agar suku ini tidak menolak akan Injil yang disampaikan, dibutuhkan strategi dalam pemberitaan Injil. Sehubungan dengan itu maka dalam penulisan skripsi ini, peneliti merumuskan permasalahan sebagai berikut : Pertama, bagaimana keadaan masyarakat yang berbudaya Melayu di DaikLingga? Kedua, srategi pemberitaan Injil apakah yang bisa dilakukan untuk penjangkauan suku Melayu di Daik-Lingga? Peneliti melakukan pendekatan terhadap suku ini dengan menggunakan penelitian kualitatif metode etnografi pada suku melayu di Daik-Lingga untuk mendapatkan data mengenai akar yang menghambat pemberitaan Injil dalam suku melayu di Daik Lingga serta strategi pemberitaan Injil yang efektif yang dapat digunakan didalam penjangkauan akan suku ini. Dari data yang telah dikumpulkan, peneliti mendapatkan hasil bahwasannya suku melayu di DaikLingga tidak menerima Injil karena faktor lingkungan yang mayoritas muslim yang tidak menginginkan pendirian budaya baru di daerahnya serta faktor orang Kristen awam yang belum mendapat pengajaran mengenai penjangkauan suku melayu.

Kata kunci: Strategi, Penjangkauan, Melayu, Daik-Lingga
\end{abstract}




\section{PENDAHULUAN}

Seringkali orang Kristen hanya sibuk dengan urusannya masing-masing dan tidak memberitakan Yesus yang adalah sangjuruselamat. Terlebih khusus mereka tidak berharap dapat meluangkan waktu dengan pemberitaan injil kepada umat non Kristen karena tidak tahu bagaimana berhubungan dengan mereka sebab pengajaran yang jelas dan berguna tidak mereka ketahui. Mereka juga jarang melihat teladan seseorang yang dapat dengan santai dan penuh percaya diri menyampaikan kebenaran Allah kepada orang-orang yang belum percaya. Oleh karena itu, mereka tidak tahu bagaimana harus memulai, sehingga banyak orang Kristen akhir-akhir ini hanya focus kepada kegiatan rutin didalam gereja saja dan mementingkan keselamatan dirinya sendiri.

Sedangkan menurut Indonesia People Network, Indonesia memiliki suku sebanyak 781, yang dalamnya 131 suku adalah suku terabaikan dengan jumlah 142.000.000 jiwa. Hal itu berarti lebih dari 65\% total penduduk Indonesia belum terjangkau. ${ }^{1}$ Dari data ini membuktikan bahwa, Indonesia membutuhkan orang-orang yang mempunyai hati untuk bergerak kepada penjangkauan suku-suku yang belum terjangkau oleh pemberitaan Injil.

Salah satu suku yang belum terjangkau oleh pemberitaan akan Injil adalah Suku melayu, terkhusus Suku Melayu di Daik Lingga- Kepulauan Riau. Suku ini perlu dijangkau dengan metode yang tepat untuk memenuhi amanat agung Tuhan Yesus sebagaimana tercatat dalam Matius 28:19-20. Oleh sebab pengenalan mereka akan Allah yang benar dan mampu menyelamatkan mereka belum mereka dapatkan.

Oleh sebab itu, seorang pemberita Injil perlu memiliki dasar yang kuat untuk melangkah dalam pemberitaan Injil agar ia memiliki iman yang kuat kepada Tuhan dan bertahan serta berjuang demi pemberitaan kabar baik yang adalah Yesus sendiri untuk dibawakan secara kontekstual kepada keselamatan suku melayu.

\section{METODE}

Dalam penulisan paper ini penulis menggunakan metode kualitatif dengan pendekatan etnografi. Metode kualitatif digunakan karena metode tersebut dapat menjelaskan fenomena dalam masyarakat yang diteliti. Dengan kata lain, objek penelitian ini adalah orang yang berkembang dalam suatu masyarakat yang berbeda budaya dan berbeda bahasa serta juga berbeda agama atau berbeda etnis. Dalam keadaan keserbabedaan tersebut masyarakat dapat dianggap sebagai suatu proses yang berkembang dan berinteraksi, kadang-kadang dalam berinteraksi tersebut tidak berlangsung harmonis tetapi tidak dikemukakan secara nyata terhadap lawan bicaranya.

Sedangkan pendekatan etnografi merupakan kegiatan pengumpulan bahan keterangan atau data yang dilakukan secara sistematik mengenai cara hidup serta berbagai aktivitas social dan berbagai benda kebudayaan dari suatu masyarakat. Dengan kata lain,

\footnotetext{
${ }^{1}$ Fransiskus Irwan Widjaja, Misiologi Antara Teori, Fakta Dan Pengalaman, 1st ed. (Batam: Andi Offset Yogyakarta, 2018).23
} 
ini berkaitan tentang kelompok budaya yang mana peneliti disini mencoba menggali arti daru suatu kebudayaan untuk bisa di tinjau dari Firman Tuhan.

\section{HASIL DAN PEMBAHASAN \\ Demografi Suku Melayu \\ Suku Melayu}

Dalam kehidupan bermasyarakat, seseorang yang hendak bersosialisasi dengan lingkungan terlebih dahulu mencari tahu identitas suatu kelompok masyarakat dengan mengungkapkan kata suku, sehingga dapat mengetahui struktur social yang jelas dari satu kelompok masyarakat. Maka, suku dapat diartikan sebagai golongan orang-orang (keluarga) yang seturunan; suku sakat; atau golongan bangsa sebagai bagian dari bangsa yang besar seperti Sunda, Jawa. ${ }^{2}$ Sedangkan pengertian Melayu itu sendiri telah berkembang mengikuti perkembangan zaman dan dinamika sejarah sejak dahulu kala sampai sekarang, di antaranya dapat di jabarkan sebagaimana berikut ini ${ }^{3}$

1. Sebutan Melayu berasal dari "Himalaya" lalu kemudian disingkat "Malaya"."Hima" berarti "salju" atau "sejuk" sedangkan "alaya" bermakna "tempat". Dengan demikian dapat disimpulkan "tempat yang sejuk seperti di puncak gunung yang tinggi".

2. Frasa Melayu dapat pula berasal dari perkataan "malaiyur-pura" yang berarti "kota malaiyur" atau "kota gunung"5

3. Kata "Melayu" dapat pula berasal dari kata "mala" dan "yu". "mala" artinya "mula" atau "permulaan" dan "yu" artinya "negeri". Melayu berarti "negerti mula"; negerti asal mula atau negeri asal usul. Diyakini bukit Siguntang di Palembang ialah negeri asal-usul rajaraja Melayu yang memerintah di Kerajaan Melayu Singapura dan Kemaharajaan Melayu Melaka serta Kemaharajaan Melayu yang kelak berpusat di Johor, Riau dan Lingga.

4. Melayu adalah nama sebuah kerajaan tua yang pernah ada di muara sungai Melayu (kini bernama Sungai Batang Hari, Jambi) dalam abad ke-7 M. penamaan sebuah kerajaan berdasarkan nama sungai hal yang biasa dalam tradisi Melayu, karena bangsa Melayu zaman dulu selalu membangun kerajaan di pinggir sungai. Sedangkan penanaman sungai sebagai "Melayu" berasal dari sifat air sungai itu sendiri yang deras atau kencang atau melaju seperti orang berlari. ${ }^{6}$

5. Melayu juga untuk menyebut bahasa yaitu bahasa Melayu yang berkembang di tengah masyarakat Melayu mulai dari zaman Kerajaan Melayu Jambi Tua, Kemaharajaan Melayu Melaka, Kemaharajaan Melayu yang meliputi Riau, Johor, Lingga dan Pahang serta Seluruh Daerah Taklukannya serta di seluruh Kerajaan Melayu di Tanah Semenanjung

\footnotetext{
2 “Suku," Kamus Besar Bahasa Indonesia., n.d., https://kbbi.web.id/suku.

3 Ahmad Dahlan, Sejarah Melayu (Jakarta: Kepustakaan Populer, 2014). 17

${ }^{4}$ Abdul Rashid Melebek and Amat Juhari Moain, Sejarah Bahasa Melayu (Kuala Lumpur: Utusan Publications \& Distributors SDN BHD, 2005).9

${ }^{5}$ Ibid. 12

${ }^{6}$ Ibid. 20
} 
(Malaysia dan Thailand Selatan), dataran tanah Sumatera dan Kalimantan Barat, termasuk Brunei Darussalam, Sabah dan Serawak. Pada suatu masa, bahasa Melayu pernah menjadi linggua franca atau bahasa pergaulan antar bangsa dalam dunia perdagangan di kawasan Nusantara, bahkan Asia Tenggara.

6. Dalam konteks prilaku, frasa "melayu" diartikan pula "layu" yang bermakna "rendah": Melayu selalu "merendah". Tapi bukan rendah diri. bangsa Melayu itu rendah hati. Menghormati pemimpin dan yang lebih tua dari dirinya. Menyebut "patik" untuk diri sendiri bila berhadapan dengan raja. Mengatakan dirinya "hamba" ketika berhadapan dengan orang tua-tua. Namun dalam pergaulan dengan teman sebaya tetap menyebut dirinya "aku" atau "saya". Dalam pergaulan di zaman sekarang "aku" atau "saya" sering pula diganti dengan sebutan "kami", dan untuk menyapa lawan bicara disebut "awak" yang artinya "kita".

Pengertian melayu pada hakikatnya merupakan suatu yang luas dan kompleks. Karena pada dasarnya melayu bangsa yang besar. Para ahli menjabarkan Melayu dalam beberapa pengertian sebagai berikut:

1. Menurut Muchtar Lutfi yang membagi pengertian "Melayu" dalam tiga pengertian sebagai berikut:

"Pertama, Ras Melayu adalah ras yang berkulit cokelat. Kedua, Suku Bangsa. Perkembangan sejarah dan perubahan politik mengakibatkan ras Melayu tersebar di seluruh Nusantara, yang terbagi dalam beberapa Negara ( Indonesia, Malaysia, Brunei Darusalam, singapura, Filipina )dan provinsi (Melayu Riau, Aceh, manado, Lombok, johor, Melaka, dll), Ketiga, Suku. Karena hanya menunjuk kepada suku tertentu yang ada di Pulau Sumatera seperi caniago, Pilang, tiga kampung, lima kampung, cermin, bodi dan lain-lain. Selain suku-suku melayu tersebut, berarti tidak termasuk suku melayu. ${ }^{7}$

2. Menurut Tengku Luckman Sinar mendeskripsikan bahwa "seseorang dianggap sebagai Melayu apabila telah memenuhi syarat sebagai orang Islam, berbicara bahasa Melayu, mempergunakan adat istiadat Melayu, dan memenuhi syarat menetap di tempat tertentu. Jadi, istilah Melayu adalah berdasarkan kultural. ${ }^{8}$

3. Menurut salah seorang keturunan sultan, Tengku Fuad mendefinisikan bahwa melayu dari penggalan kata "Me" yang berarti Mohammad S.W.T, "Lam" yaitu La ilaha Illallah, "Yu" yang berarti bumi, "Waw" yang berarti Warah (Taqwa, Suci, Bersih, Taat). Sehingga, Melayu hanya takluk kepada yang satu yaitu Allah dan dia berkembang sesuai dengan agama Islam. ${ }^{9}$

\footnotetext{
${ }^{7}$ Lutfi H. Muhctar, Melayu Dan Non Melayu : Masalah Pembauran Kebudayaan Dalam Masyarakat Melayu Dan Budaya Melayu Dalam Perubahan (Yogyakarta: Balai kajian dan Pengembangan Budaya melayu, 2007).38 2005).3

${ }^{8}$ Tengku Luckman Sinar, Adat Budaya Melayu Jati Diri Dan Kepribadian (Sumatera Utara: Forkala,

${ }^{9}$ Tengku Fuad, "Wawancara Dengan Tengku Fuad Seorang Keturunan Sultan Dari Penyengat Tgl. 26 Februari 2019 Pkl. 09.23 WIB," 2019.
} 
Jadi jika di artikan kata Melayu dari cerita rakyat dapat diartikan sebagai sebuah negeri yang mula-mula didiami, berada di sekitar atau tepian sungai sedangkan Melayu dalam arti sempit merujuk kepada ras atau suku yang mendiami sebagian wilayah Asia Tenggara. Dan Melayu dalam arti luas dimaknai sebagai sebuah kultur, artinya Melayu adalah setiap tempat, komunitas, kelompok masyarakat ataupun daerah di belahan dunia manapun yang masih atau pernah menjalankan tradisi Melayu. Tradisi yang dijalankan/diberlakukan tersebut merupakan kepribadian orang Melayu yang dibentuk oleh adat istiadat Melayu yang terimplementasikan dalam cara berpikir, bersikap, dan bertingkah laku yang tidak lepas dari hukum Islam.

Untuk Suku Melayu Riau adalah salah satu dari banyak Rumpun Melayu yang ada di nusantara. Mereka berasal dari daerah Riau yang menyebar di seluruh wilayah sampai ke pulau-pulau terkecil yang termasuk dalam wilayah provinsi Riau dan kepulauan Riau. Daik - Lingga merupakan salah satu kabupaten di Provinsi Kepulauan Riau, Indonesia. Kabupaten Lingga memiliki 9 kecamatan, 7 kelurahan, dan 74 desa. ${ }^{10}$

Masyarakat Melayu di Daik Lingga ini sangat menjunjung tinggi adat dan budaya mereka sehingga tertanam dalam jiwa masyarakat melayu, budaya harus dijunjung tinggi dan dipelihara. Pepatah melayu mengatakan "tak melayu hilang dibumi" yang artinya karena cintanya terhadap budaya dan adat istiadat melayu hingga sekarang dalam kehidupan sehari-hari adat dan budaya melayu terus dikembangkan.

\section{Paradigma Suku Melayu di Daik Lingga}

Suku melayu di Daik Lingga telah mengadopsi sikap paradoks yaitu mengadopsi budaya dan kebiasaan setempat untuk bertahan hidup, tetapi dipihak lain, memelihara kesadaran sebagai orang melayu dengan menjalankan kepercayaan, tradisi, bahasa, dan norma-norma etnisitas mereka. Hampir seluruh aktifitas masyarakat suku melayu di Riau antara lain dalam pelaksanaan upacara perkawinan, upacara keselamatan/kenduru, upacara kematian, hari besar Nasional, hukum waris, kesenian, cara berpakaian, tatakrama, adat istiadat, bahasa, dan sebagainya masih berlandaskan syariah Islam. ${ }^{11}$

Suku melayu memiliki pandangan yang tinggi terhadap ajaran agama islam dan iman yang fundamental sehingga memberikan penilaian terhadap fenomena di tengah masyarakat bahwa melayu itu adalah Islam.

Terkhusus suku melayu di kepulauan Riau di daerah bagian pesisir (suku laut), karena rendahnya perekonomian sehingga mereka cenderung menerima sponsor dari pemerintah untuk menjadi seorang muslim. Oleh karena itu, mayoritas agama yang berada di daerah ini ialah agama Islam. Tidak hanya itu, banyak faktor yang mempengaruhi sulitnya suku ini menerima injil seperti faktor dari penjajah yang ingin menguasai suku ini sehingga image tentang budaya barat ialah budaya orang Kristen yang hendak menguasai

\footnotetext{
10 “Kabupaten Lingga," 2019, https://id.wikipedia.org/wiki/Kabupaten_Lingga.

${ }^{11}$ Stephen Tong, Apa Yang Kami Percaya? (Surabaya: Momentum, 2013).35
} 
wilayah kekuasaan mereka maka mereka menempatkan daerahnya ke tempat yang strategis dan sulit di jangkau oleh budaya asing dan membungkus daerahnya dengan adat istiadat melayu. Dengan kata lain, ini adalah strategi sultan untuk menghindari serangan balik pihak belanda dan mengusir Belanda sehingga negeri Melayu tidak di jajah oleh penjajah bangsa Belanda yang ingin menguasai daerah melayu. ${ }^{12}$

\section{Faktor Suku Melayu Mendefinisikan Diri sebagai Agama Islam}

Menurut Muhammad Naquib al-Attas ada beberapa teori tentang kedatangan dan penyebaran Islam di kepulauan Melayu, ini merupakan faktor yang menyebabkan orang Melayu mengidentifikasikan diri dan peradabannya dengan Islam, berikut ini faktorfaktornya: ${ }^{13}$

1. Faktor perdagangan

2. Faktor perkawinan, yaitu antara pendatang Muslim dengan wanita pribumi pada tahap awal kedatangan Islam;

3. Faktor permusuhan antara orang-orang Islam dan Orang Kristen

4. Faktor politik seperti mundurnya kerajaan Hindu dan Budha seperti Majapahit dan Sriwijaya;

5. Faktor penghargaan nilai ideology Islam

6. Faktor Otoktomi, atau keadaan dimana sesuatu itu dianggap telah ada sejak purbakala sebagai kepunyaan atau sifat kebudayaan suatu masyarakat.

Dari beberapa faktor diatas, melalui faktor perdagangan yang menjadi pusat penyebaran agama Islam di daerah Melayu sebab pengaruh penyebaran agama Islam sangat kuat diterima oleh masyarakat Melayu karena aspek kesetaraan manusia, yang menurut ideology masyarakat kala itu menganut sistem kasta dalam Hindu, dimana masyarakat kasta kelas bawah lebih rendah dari anggota kasta yang lebih tinggi. ${ }^{14}$ Selain itu, alasan lainnya yang membuat islam dapat di terima ialah pelaksanaan ibadah yang sederhana dan biaya murah, hanya cukup mengucapkan kalimat syahadat, aturan-aturan dalam Islam bersifat fleksibel dan tidak memaksa, penyebaran agama Islam di Indonesia di lakukan secara damai tanpa kekerasan dan di sesuaikan dengan kondisi social budaya yang ada, runtuhnya kerajaan majapahit pada abad ke 15 yang memudahkan penyebaran agama Islam tanpa ada pembatasan dari otoritas kerajaan Hindu-Budha. ${ }^{15}$ Sehingga hal-hal ini membuat agama Islam menjadi landasan untuk suku tersebut.

\footnotetext{
${ }^{12}$ David Garisson, A Wind in the House of Islam: How God Is Drawing Muslims Around the World to Faith in Jesus (WIGTake Resources, 2014).19

${ }^{13}$ Muhammad Naquib Al-Attas, Islam Dalam Sejarah Dan Kebudayaan Melayu (Jakarta: Angkatan Belia Islam Malaysia, 1999).43 1956). 170

${ }^{14}$ F. Wertheim W, Indonesian Socienty in Transition: A Study of Social Change (Bandung: W.Van Hoeve,

${ }^{15}$ Pengambilan Data Di Museum Sultan Sulaiman Badrul Alamsyah Tanjung Pinang, n.d.
} 


\section{Pentingnya Injil Terhadap Suku Melayu}

Suku melayu sangat penting untuk di jangkau oleh sebab suku tersebut, belum mengenal dan mengaku Yesus Kristus sebagai Tuhan dan Juruselamat sebagaimana tercatat dalam Yohanes 14:6, Kata Yesus kepadanya: "Akulah jalan dan kebenaran dan hidup. Tidak ada seorang pun yang datang kepada Bapa, kalau tidak melalui Aku." dan dalam Roma 10:9-10 "Sebab jika kamu mengaku dengan mulutmu, bahwa Yesus adalah Tuhan, dan percaya dalam hatimu, bahwa Allah telah membangkitkan Dia dari antara orang mati, maka kamu akan diselamatkan. Karena dengan hati orang percaya dan dibenarkan, dan dengan mulut orang mengaku dan diselamatkan". Mereka mengimani hanya satu Tuhan yaitu Allah. Dia tidak dapat dicapai oleh penglihatan mata, sedang Dia dapat melihat segala yang kelihatan dan Dialah yang maha halus lagi maha mengetahui (Al - An'am 6:103). Dia memandu manusia pada jalan yang lurus "jalan yang diridhaiNya" dan Allah menurunkan firman-Nya kepada manusia melalui para nabi dan rasul utusan-Nya, dan meyakini dengan sungguh-sungguh bahwa Muhammad SAW adalah Nabi terakhir.

Dalam penyebutan nama allah, muslim menyatakan bahwa Allah adalah nama dari satu-satunya allah mereka, tetapi hal ini sama sekali tidaklah benar. Kenyataannya allah adalah nama berhala dewa bulan yang adalah dewa utama mereka diantara sekitar 360 berhala di Ka'bah (kuil) di Mekah. Ini telah disembah di Timur Tengah untuk waktu yang lama sebelum Islam berdiri. Hal ini telah dilakukan hingga di masa kini, seperti puasa Ramadhan adalah contoh khas yang menunjukkan penyembahan Islam terhadap dewa bulan. Mereka berpuasa untuk meratapi bulan yang telah kehilangan kuasa karena matahari dan ketika bulan muncul, mereka akhirnya bangkit dan mereka makan dan bersukaria. Melalui puasa Ramadhan, umat Muslim mengungkapkan penghormatan mereka yang terdalam terhadap bulan. ${ }^{16}$ Sedangkan dalam Ulangan 4:19, Allah berfirman "dan juga supaya jangan engkau mengarahkan matamu ke langit, sehingga apabila engkau melihat matahari, bulan dan bintang, segenap tentara langit, engkau disesatkan untuk sujud menyembah dan beribadah kepada sekaliannya itu, yang justru diberikan Tuhan, Allahmu, kepada segala bangsa di seluruh kolong langit sebagai bagian mereka." Itu berarti, pengenalan mereka akan Allah yang benar dan mampu menyelamatkan mereka itu tidak mereka dapatkan.

Dengan kata lain, mereka hanya mendapatkan penyataan umum yang di rasakan secara universal. Kata penyataan menunjuk pada tindakan Allah untuk membuat diriNya sendiri diketahui dan dikenal oleh manusia. Penyataan umum membahas mengenai Allah pencipta langit dan bumi, tentang manusia sebagai ciptaan Allah, tentang dosa sebagai persoalan mendasar manusia, atau tentang neraka sebagai tempat penghukuman kekal sebagai dampak dosa, relevan bagi semua orang, yang mana semua manusia memiliki kesadaran bahwa Allah ada. ${ }^{17}$ Tetapi, penyataan khusus yang menyatakan Allah sebagai

\footnotetext{
16 Thomas Hwang, Asal-Usul Agama-Agama (Korea: Sarah Hae-Ok Cho, 2013).120

${ }^{17}$ Iswara Rintis Purwantara, Prapenginjilan (Yogyakarta: Andi Offset Yogyakarta, 2012).58
} 
yang memperbaiki dan menyempurnakan segala sesuatu tidaklah mereka dapatkan. Seperti halnya penyataan khusus adalah penyataan yang dipakai Tuhan untuk memberikan kepada manusia $^{18}$ :

1. Perbaikkan dari penyataan umum. Yang mana Ia sebagai yang bijaksana, yang kuasa, yang suci dan adil. Berbeda dengan penyataan umum yang diungkapkan lewat alam, tidak diterangkan bahwa Tuhan itu Yang suci.

2. Dalam penyataan khusus, Tuhan memberikan apa yang tidak tercantum dalam penyataan umum yaitu petunjuk tentang kelepasan dari dosa. Sebab penyataan umum tidak dijuruskan kepada keadaan yang berdosa tetapi keadaan sebelum berdosa. Dengan penyataan khusus, Tuhan menyatakan diri kepada manusia, bahwa Ia sudah damai lagi dengan manusia di dalam Tuhan Yesus Kristus.

Di sisi lain, suku ini memiliki kepercayaan pada arwah yang dapat menghubungkan doa mereka dengan tuhan dan juga pantang larang. Sehingga pada saat mereka berziarah, mereka akan meminta keinginan yang belum terpenuhi dalam kehidupan mereka kepada para nenek moyang mereka serta masuk di dalam kuburan, harus ada aturannya. ${ }^{19}$

Sedangkan dalam firman Tuhan Ulangan 18:11-12 sudah menyatakan bahwa "seorang pemantera, ataupun seorang yang bertanya kepada arwah atau kepada roh peramal atau yang meminta petunjuk kepada orang-orang mati. Sebab setiap orang yang melakukan hal-hal ini adalah kekejian bagi Tuhan, dan oleh karena kekejian-kekejian inilah Tuhan, Allahmu menghalau mereka dari hadapanmu”. Untuk itulah, sangat penting bagi orang percaya untuk dapat memberitakan Kristus dengan cara yang tepat untuk menjangkau suku tersebut.

\section{Metode Membawa Injil Kepada Budaya Melayu Di Daik Lingga}

Menghadirkan Injil kedalam budaya melayu, perlu memakai metode yang benar, dan metode yang benar dapat dil lihat selain dari pada Yesus, ada paulus yang memakai pendekatan kontekstualisasi yaitu pendekatan kepada budaya di Listra (Kis 14:8-20). Dalam penyampaian Injil, Ia memakai sikap dan metode kontekstualisasi dalam mengkemas berita yang ia sampaikan.

Sebelumnya, ia menjangkau Athena (Kis. 17) dan menyadari bahwa komunitas itu bukanlah orang-orang yang mempunyai Taurat (seperti Yahudi) dan yang tidak mempercayai Allah yang monoteisme maka ia terlebih dahulu "menggiring" pemahaman orang-orang Athena kepada teologi naturalisme. Pemberitaannya berangkat dari konsep "allah yang tidak kamu kenal." Dari hal tersebut, ia menyeberangkan konsep tersebut kepada Allah yang tidak diciptakan oleh tangan manusia dan yang tidak tinggal dalam batu dan kayu. Kemudian di Listra (Kis. 14) . Dalam hal ini, penduduk Listra telah menafsirkan mujizat kesembuhan yang terjadi setelah salah satu khotbah Paulus sebagai manifestasi

\footnotetext{
${ }^{18}$ R. Soedarmo, Ikhtisar Dogmatika (Jakarta: BPK Gunung Mulia, 2009).33

${ }^{19}$ Sinar, Adat Budaya Melayu Jati Diri Dan Kepribadian.4
} 
kuasa ilahi yang menunjukan bahwa Barnabas dan Paulus adalah dewa yang menyamar. Karena pada konteks kepercayaan kebudayaan daerah tersebut ialah kepada dewa Zeus. Oleh sebab itu, mereka tidak bisa dengan mudah membedakan antara dewa dan manusia. sehingga Paulus harus menjelaskan kepada penduduk yang ada di LIstra tentang Allah yang hidup dan yang benar.

Jadi, Paulus tidak berhenti pada teologi naturalisme atau teologi universalime dan tidak berhenti pada teologi Allah yang universal, namun pada kenyataannya ia kemudian membawakannya lagi kepada penyataan Allah yang khusus di dalam Yesus Kristus. Jadi rangkaian pendekatan dalam pemberitaannya di kota Listra: "Tuhan" tak berpribadi $\rightarrow$ Tuhan yang hidup (Allah yang universal) $\rightarrow$ Tuhan yang berinkarnasi (penyataan khusus di dalam Yesus Kristus). ${ }^{20}$

Selain itu, ia memakai ilustrasi-ilustrasi yang menunjukkan kehidupan khas dari kota Listra yang diawali dari latar belakang bahwa kota ini banyak pertempuran militer zaman dulu terjadi di sana sehingga ia menegaskan bahwa "senjata kami dalam perjuangan bukanlah senjata duniawi, melainkan senjata yang diperlengkapi dengan kuasa Allah, yang sanggup untuk meruntuhkan benteng-benteng (II Kor 10:4)”. Serta dalam konteks pelayanan Paulus, ia memberitakan Injil pada orang non Yahudi tanpa harus meyahudikan mereka; orang non Yahudi tidak dituntut untuk disunat. ${ }^{21}$ Oleh karena itu, berikut secara rinci metode yang dapat di pakai dalam menghadirkan Injil ke dalam budaya Melayu Riau di Daik Lingga :

\section{Memahami Kebudayaan Mereka}

Suku Melayu sangat mencintai kebudayaan mereka sehingga apapun yang mereka lakukan harus berdasarkan adat istiadat budaya melayu yang berlandaskan syariah Islam. Oleh karena itu, kita perlu memulai persahabatan dengan membahas soal-soal yang digemari oleh orang melayu yaitu budaya. Kita dapat memakai pantun dalam bahasa mereka, berpakaian seperti mereka, mengikuti kegiatan budaya mereka yang masih sesuai dengan firman Tuhan. Hal ini dapat diketahui ketika kita berada bersama-sama dengan mereka dengan melakukan penyesuaian diri (pendekatan kontekstualisasi). Respon mereka akan menerima kita saat kita memulai dengan memahami pikiran dan kebutuhan kehidupan mereka.

Penyesuaian diri dengan kebudayaan masyarakat yang belum diselamatkan itu perlu didasarkan atas pemikiran yang sangat meyakini bahwa didalam Kristus Yesus hal bersunat atau tidak bersunat tidak mempunyai sesuatu arti, hanya iman yang bekerja oleh kasih (Galatia 5:6). Dengan kata lain, Pemberita Injil harus mati terhadap keakuannya sendiri untuk menjadi serupa dengan kelompok masyarakat yang belum bisa diselamatkan itu. Hal itu akan terlihat dalam upayanya untuk mengubah kebiasaan-kebiasaannya sendiri

\footnotetext{
${ }^{20}$ J.H. Bavinck, Sejarah Kerajaan Allah (Jakarta: BPK Gunung Mulia, 2012).778

${ }^{21}$ Paul Enns, The Moody Handbook Of Theologhy (Malang: Literatur SAAT, 2012). 124
} 
supaya mengikuti norma-norma dari kelompok masyarakat yang terabaikan. Ia sengaja mengenakan pakaian yang dianggap pantas oleh mereka, berbicara dalam bahasa mereka, dan menyantap makanan mereka, serta mengharamkan apa yang mereka haramkan (misalnya tidak makan daging babi di kalangan suku Melayu).

Memakai bahasa daerah atau istilah-istilah keagamaan dari kelompok suku perlu menggunakan nama Isa (bagi agama Islam). Karena mereka akan merasa kurang tepat jikalau seorang pemberita Injil menggunakan penyebutan Juruselamat manusia yaitu Yesus. Oleh sebab itu, seorang pemberita Injil perlu memakai bahasa dan kebiasaan dari masyarakat yang hendak di layani untuk mengajarkan pengertian-pengertian Alkitab kepada mereka. Oleh sebab itu, seorang pemberita Injil perlu menyesuaikan diri dengan masyarkakat yang hendak dilayani. Dengan menunjukkan ketaatan kepada Tuhan dan FirmanNya dalam konteks budaya kelompok suku yang bersangkutan, menyediakan sebuah contoh yang dapat ditiru oleh jiwa-jiwa yang dijangkau (1 Kor 11:1).

Seorang pemberita Injil harus siap di tolak atau diterima oleh para warga dari kelompok suku fokus, seperti yang dialami oleh Yesus sendiri (Yoh 1:11-12). Mereka harus siap sedia untuk menangkis segala fitnahan dan salah pengertian terhadap pelayanan mereka.

\section{Melakukan Pendekatan Lintas Budaya}

Pendekatan lintas budaya ialah suatu keadaan dimana sebuah kebudayaan dapat dilalui sehingga terjadi proses akulturasi budaya akibat dari pengarus perlintasan budaya tersebut. Dengan memakai pendekatan lintas budaya, seseorang dapat mengidentifikasi diri dengan masyarakat yang dilayani. Untuk itu, seorang misionaris perlu menguasai bahasa mereka, menenggelamkan diri dalam kebudayaan mereka, belajar berpikir seperti mereka berpikir, berperasaan dan berperilaku seperti mereka juga. Tidak boleh ada sedikit pun jarak antara gaya hidup misionaris dan gaya hidup masyarakat di sekeliling. Untuk itu kita harus banyak meluangkan waktu bersama mereka dengan mendengarkan dan mempelajari bahasa mereka dan budaya mereka serta membantu mereka dalam kegiatan keseharian mereka jika situasi memungkinkan. ${ }^{22}$

Standar kehidupan yang dipilih harus begitu rupa sehingga dapat mengekspresikan kasih sayang yang penuh keperdulian dan kerelaan untuk berbagi. Standar itu sedemikian rupa sehingga menjadi sangat wajar untuk tolong- menolong tanpa harus merasa malu, yaitu menunjukkan kemurahan tangan secara timbal balik, hingga diri kita sudah merasa sebagai bagian dari masyarakat yang bersangkutan dan masyarakat itu sendiri merasa bahwa diri kita telah menjadi bagian dari mereka.

Dengan begitu, kita mendapatkan kepercayaan mereka kepada kita namun hendaknya juga kita harus menaruh sikap melayani dan bukannya mendominasi atau

\footnotetext{
${ }^{22}$ Manahan U. Simanjutak, Diktat Misi Lintas Budaya STT Real Batam (STT Real Batam, 2014).25
} 
mengatur. Dalam arti, ringan tangan dalam membantu pekerjaan mereka. Dengan hal demikian, Injil dapat diberitakan tanpa ada penolakkan dari mereka.

\section{Menggunakan Metode Bercerita dengan Media Secara Kontekstual}

Suku melayu akan merespon pemberitaan Injil jikalau kita mengawali dengan percakapan yang dapat membangun persahabatan dengan mereka. Agar suasana persahabatan dapat terjadi, seorang pemberita Injil perlu berkomunikasi dengan bahasa ibu (bahasa setempat) dan memulai dengan membahas soal-soal yang digemari oleh orang melayu. Dengan melakukan percakapan seperti ini, kita mendapatkan kepercayaan mereka terhadap diri kita sehingga apapun yang ingin kita sampaikan, mereka dapat menerima.

Cerita mempunyai kekuatan untuk mengubah cara orang berpikir, berperasaan, dan bertingkah laku, dan mengubah pandangan yang umum diantara mereka. Oleh karena suku melayu identic dengan komunikasi lisan, hendaknya kita mempunyai proses teratur untuk membawa mereka kepada suatu pandangan yang alkitabiah melalui cerita-cerita yang dikaitkan dengan pandangan hidup suatu suku dan dalam membimbing mereka, cara kita bercerita harus membuat para pendengar berhasil memetik pelajaran dari sana. Menekankannya untuk diri sendiri, untuk kemudian diteruskan kepada yang lain. Itulah sebabnya, sangat penting cerita disampaikan secara langsung oleh para mereka yang berbicara dalam bahasa ibu. Strategi bercerita sangat tepat untuk mereka yang belum terjangkau. Untuk itu,perlu juga menggunakan sarana penginjilan dengan memakai media atau jembatan alquran untuk pemberitaan Injil. Sebagai contoh penggunaan media secara kontekstual, terlampir pada Lampiran.

\section{KESIMPULAN}

Dalam membawa Injil ke dalam budaya melayu di Daik Lingga, kita terlebih dahulu "menjadi seperti" (1 Korintus 9:19-22) dimana kita dapat bersosialisasi dengan mereka, menjadikan status kita itu adalah menjadi pelajar dari budaya setempat serta memakai pemberitaan Injil dengan kontes budaya mereka lewat kehidupan kita secara langsung, penggunaan media yang membuka paradigma mereka, dan membawa mereka mengerti dengan kehidupan yang sesungguhnya di dalam Isa Almasih (Yesus Kristus). Dengan kata lain, cara kita membawa Allah ke dalam semua percakapan kita dengan cara yang alami.

Untuk itulah seorang pemberita Injil perlu memperkaya dirinya dengan mempelajari cara komunikasi lisan yang efektif, menggunakan sarana penginjilan sesuai budaya masyarakat setempat. Cara efektif ini dapat diketahui melalui pengamatan saksama dan membaur dalam komunitas tersebut. Dengan cara pemberitaan Injil secara kontekstual yang tepat, para pendengar (suku Melayu) akan larut dalam inti cerita yang disampaikan. 


\section{KEPUSTAKAAN}

Al-Attas, Muhammad Naquib. Islam Dalam Sejarah Dan Kebudayaan Melayu. Jakarta: Angkatan Belia Islam Malaysia, 1999.

Bavinck, J.H. Sejarah Kerajaan Allah. Jakarta: BPK Gunung Mulia, 2012.

Dahlan, Ahmad. Sejarah Melayu. Jakarta: Kepustakaan Populer, 2014.

Enns, Paul. The Moody Handbook Of Theologhy. Malang: Literatur SAAT, 2012.

Fuad, Tengku. "Wawancara Dengan Tengku Fuad Seorang Keturunan Sultan Dari Penyengat Tgl. 26 Februari 2019 Pkl. 09.23 WIB," 2019.

Garisson, David. A Wind in the House of Islam: How God Is Drawing Muslims Around the World to Faith in Jesus. WIGTake Resources, 2014.

Hwang, Thomas. Asal-Usul Agama-Agama. Korea: Sarah Hae-Ok Cho, 2013.

Melebek, Abdul Rashid, and Amat Juhari Moain. Sejarah Bahasa Melayu. Kuala Lumpur: Utusan Publications \& Distributors SDN BHD, 2005.

Muhctar, Lutfi H. Melayu Dan Non Melayu: Masalah Pembauran Kebudayaan Dalam Masyarakat Melayu Dan Budaya Melayu Dalam Perubahan. Yogyakarta: Balai kajian dan Pengembangan Budaya melayu, 2007.

Purwantara, Iswara Rintis. Prapenginjilan. Yogyakarta: Andi Offset Yogyakarta, 2012.

Simanjutak, Manahan U. Diktat Misi Lintas Budaya STT Real Batam. STT Real Batam, 2014.

Sinar, Tengku Luckman. Adat Budaya Melayu Jati Diri Dan Kepribadian. Sumatera Utara: Forkala, 2005.

Soedarmo, R. Ikhtisar Dogmatika. Jakarta: BPK Gunung Mulia, 2009.

Tong, Stephen. Apa Yang Kami Percaya? Surabaya: Momentum, 2013.

W, F. Wertheim. Indonesian Socienty in Transition: A Study of Social Change. Bandung: W.Van Hoeve, 1956.

Widjaja, Fransiskus Irwan. Misiologi Antara Teori, Fakta Dan Pengalaman. 1st ed. Batam: Andi Offset Yogyakarta, 2018.

"Kabupaten Lingga," 2019. https://id.wikipedia.org/wiki/Kabupaten_Lingga.

Pengambilan Data Di Museum Sultan Sulaiman Badrul Alamsyah Tanjung Pinang, n.d.

"Suku." Kamus Besar Bahasa Indonesia., n.d. https://kbbi.web.id/suku. 